\title{
Optimal water allocation based on agricultural and environmental water value
}

\section{Amir Hatamkhani}

Shahid Beheshti University

Ali Moridi ( $\boldsymbol{D}$ a_moridi@sbu.ac.ir)

Shahid Beheshti University https://orcid.org/0000-0002-3974-2170

\section{Research Article}

Keywords: Water allocation, Environmental flow, Wetland, WEAP, Optimization, Ecosystem services, Development, Economic

Posted Date: October 18th, 2021

DOl: https://doi.org/10.21203/rs.3.rs-730925/v1

License: (1) This work is licensed under a Creative Commons Attribution 4.0 International License. Read Full License 


\title{
Optimal water allocation based on agricultural and environmental
}

\author{
water value
}

\author{
Amir Hatamkhani, Ph.D. Student, Civil, water and environmental engineering faculty, Shahid \\ Beheshti University, Tehran, Iran. Email: a_hatamkhani@sbu.ac.ir \\ Ali Moridi, Assistant Professor, Civil, water and environmental engineering faculty, Shahid \\ Beheshti University, Tehran, Iran. Email: a moridi@sbu.ac.ir
}

\begin{abstract}
Despite the significant role of wetlands in maintaining a healthy ecosystem and providing various ecosystem services, they are under threat due to human activities and agriculture use. The fact that the economic value of ecosystem services is not considered in hydro-economic models and integrated water resources management is a key issue that affects the ecosystem and its degradation. the economic value of ecosystem services provides a quantitative and important basis for the reasonable management of water resources. Given that supplying the agriculture and environmental demands conflict with each other, achieving a balance between these goals is very important. So, in this study, a simulation-optimization (WEAP-PSO) approach is employed for optimal planning at the basin and designing environmental flow based on wetland ecosystem services. The objective function of the problem is considered to be the total economic value of the river, which includes the economic value of the agricultural sector and the economic value of the wetland ecosystem services. The decision variables of the problem are considered as, the cultivation area of agricultural units and environmental flow of Kani Barazan wetland. The results show that considering these two objectives together, in addition to sustainable development, causes the highest economic efficiency in the basin.

Keywords: Water allocation, Environmental flow, Wetland, WEAP, Optimization, Ecosystem services, Development, Economic
\end{abstract}




\section{Introduction}

Countries such as Iran, with an arid and semi-arid climate, face water shortage problems due to inadequate temporal and spatial distribution of water, as well as population growth, urbanization, and the development of agriculture and industry. Increasing water demand and its continuity have widened the gap between water supply and demand. Therefore, optimal and sustainable management and utilization of available water resources are essential to prevent water crisis. Hydro-economic models are often used to evaluate water resources management options, commonly with a goal of understanding how to maximize water use value and reduce conflicts among competing uses.

In recent years, many hydro-economic models have addressed the issue of integrated management and planning of water resources for various goals. Some researchers have focused on only one economic sector like agriculture (Sherafatpour et al (2019), Hatamkhani and Moridi (2021), Roozbahani et al (2013), ) or hydropower (Hatamkhani et al. (2020)) and others have planned water resources intending to maximize the benefits of several economic sectors: agriculture and domestic (Karimi and Ardakanian (2010), Haavisto et al (2019)), Agriculture and hydropower (Bielsa and Duarte (2001), Hatamkhani and Moridi (2019)), Agriculture and industry (Davijani 2016), Agriculture and industry and domestic (Liu et al (2010), Wang et al (2015)) can be mentioned. By reviewing studies on the optimal allocation of water resources, it's clear in most studies, environmental needs have either been ignored altogether or have been considered as a constraint in the mathematical planning model (Momblanch et al. 2016). In hydro-economic models, agricultural economics, industry and urban demands are usually considered, and environmental economics is not considered as an important part of the basin that guarantees sustainable development. Our natural environment provides us with a variety of services that contribute to our 
economic well-being. The fact that the economic value of these services is not considered in decision-making is a key issue that affects the ecosystem and its degradation. Thus, the valuation of ecosystem services provides an opportunity to price previously unpaid ecosystem services, such as improving climate conditions, regulating water quality, and providing plant and animal habitat, so that these services can enter into economic relations. Understanding the quantity and spatial distribution of ecosystem services, along with their associated economic value, is a fundamental first step to developing effective means of ensuring the long-term provision of services by natural ecosystems (Underwood et al. 2018). Wetlands account for $40.6 \%$ of the total global ecosystem services (ES) value (Costanza et al. 2014). Globally, many wetlands have been exploited or used unsustainably (Rebelo et al., 2017), which has resulted in a 35\% loss in the global wetland extent since 1970 (Ramsar Convention on Wetlands, 2018). The importance of maintaining wetland hydrology and flow regime for ecosystem services has been widely recognized (Bunn and Arthington, 2002). Sustainable environmental flows (e-flow) are essential to the wetlands for the restoration and rehabilitation of the ecosystem services.

Wetlands in Iran are increasingly under pressure due to human activity. Undoubtedly the most serious threats to wetlands have been their drainage and reclamation for agriculture and the diversion of water supplies for irrigation (World Bank 2005). On the other hand, agriculture has special importance in many parts of Iran and in addition to providing food security, the livelihood of many people depends on it.

Designing environmental flows is a challenge for researchers and managers, given their complexity and their importance, both for nature conservation and economy. However, the rapid growth of the human population has put these areas under increasing pressure that threatens their ecological integrity and economic value (Belmar et al. 2019). In general, methods for designing 
environmental flows with a primary objective of ecosystem protection have been divided into four groups: hydrological, hydraulic, habitat, and holistic methods (Alczar et al., 2008).

Protection of the environmental flow naturally restricts the availability of water for the development of other water sectors, especially the agricultural water sector (Xue et al. 2017). Due to these effects, studies examining economic loss caused by reasonable protection of the environmental flow have been undertaken but no economic evaluation for ecological services is estimated (Qureshi et al. 2007, Pang and Sun 2014).

The economic value of service functions of the ecosystem can provide a quantitative and important basis for the reasonable management of water resources. The value of environmental flow and the cost and related compensation of e-flow protection have been the new leading directions of e-flow research in recent years and are still at the exploration stage, but there have already been several researchers that have proposed their original viewpoints. Akter et al. presented a method for combining hydro-ecological response model outputs and nonmarket economic values of wetland inundation to estimate a unit price of e-flow. Yang et al. (2014) quantified ecosystem services values and used the results to design an environmental flows regime for Baiyangdian Lake, the largest shallow freshwater lake in northern China. To do so, they proposed explicit tradeoffs among ecosystem services and used emergy analysis to value the lake's ecosystem services from 1980 to 2011.

Gopal (2016) presented a conceptual framework for the assessment of e-flows on the basis of a change in total ecosystem services and their total economic value with the alteration of flow regimes. Yue et al. (2018) combined the definition and implication of river ecological base flow to analyze the ecological services of the river base flow of rivers during the flood season and the non-flood period and finally calculated the economic value of the ecological base flow in the five 
sections of the Guanzhong section of Weihe River. Cao et al. (2020) estimated the total and individual land ecosystem services value (lake, marsh, and terrestrial land) of the Baiyangdian and quantified the relationship between ecosystem services value and water storage in the macrophytedominated shallow lake, taking water level as the indicator.

Although the quantitative studies on the economic value of service functions of the rivers and wetlands enable us to understand their economic benefits and importance in our daily lives, application of the economic value of ecosystem services in integrated water resources management (IWRM) and estimating the e-flow based on the economic value of ecosystem services have not got enough attention. To maintain the ecological service function and ensure the corresponding economic value of different sectors, we should consider the process of the dynamic change of the economic value of these sectors for planning water resources and determining the e-flow. Therefore, when planning water resources in the catchment, both of these cases should be considered in the hydro-economic model to achieve sustainable and efficient development. Therefore, the optimal allocation and development of water resources between the environment and agriculture sectors (which are extremely competitive in Iran) are very important. For this purpose, the optimization-simulation approach has been employed in this study. First, the waterrelated ecosystem services of wetland are evaluated. Then, using the optimization-simulation model and the relationship and interaction between the economic value of the wetland and agriculture, the optimal planning of water resources in the basin and the design of e-flow is investigated. WEAP (Water Evaluation And Planning) software is used to simulate the water resources system and PSO (particle swarm optimization) is used as an optimization algorithm. The developed model is employed for Mahabad catchment and Kani Barazan wetland in northeastern Iran. 


\section{Material and methods}

\subsection{Value Method of E-flow}

The relationship between the economic and ecological services functions is contradictory (Gopal, 2016), i.e., the greater the water resource used for the economic sectors, the smaller the water resources used for the ecological base flow of rivers. Therefore, suppose the inflow of rivers is constant, the change in the amount of water in any water use sectors (economic water use or ecological water use) would lead to the change in the amount of water in other water use sectors, which would further cause the change in the total economic value functions of rivers.

When the water requirement of economic services functions or ecological services functions of rivers reached a certain value, the total economic value produced by ecosystem services functions of rivers would achieve the maximum value (indicated by P point in Fig. 1). At this time, the water demand of the ecological service functions of rivers would be the recommended ecological base flow of rivers (see Fig. 1).

In recent years, water interception by dams upstream of the wetland and excessive water use by the inhabitants of the watershed has resulted in decreasing water depth in the Baiyangdian Wetland 


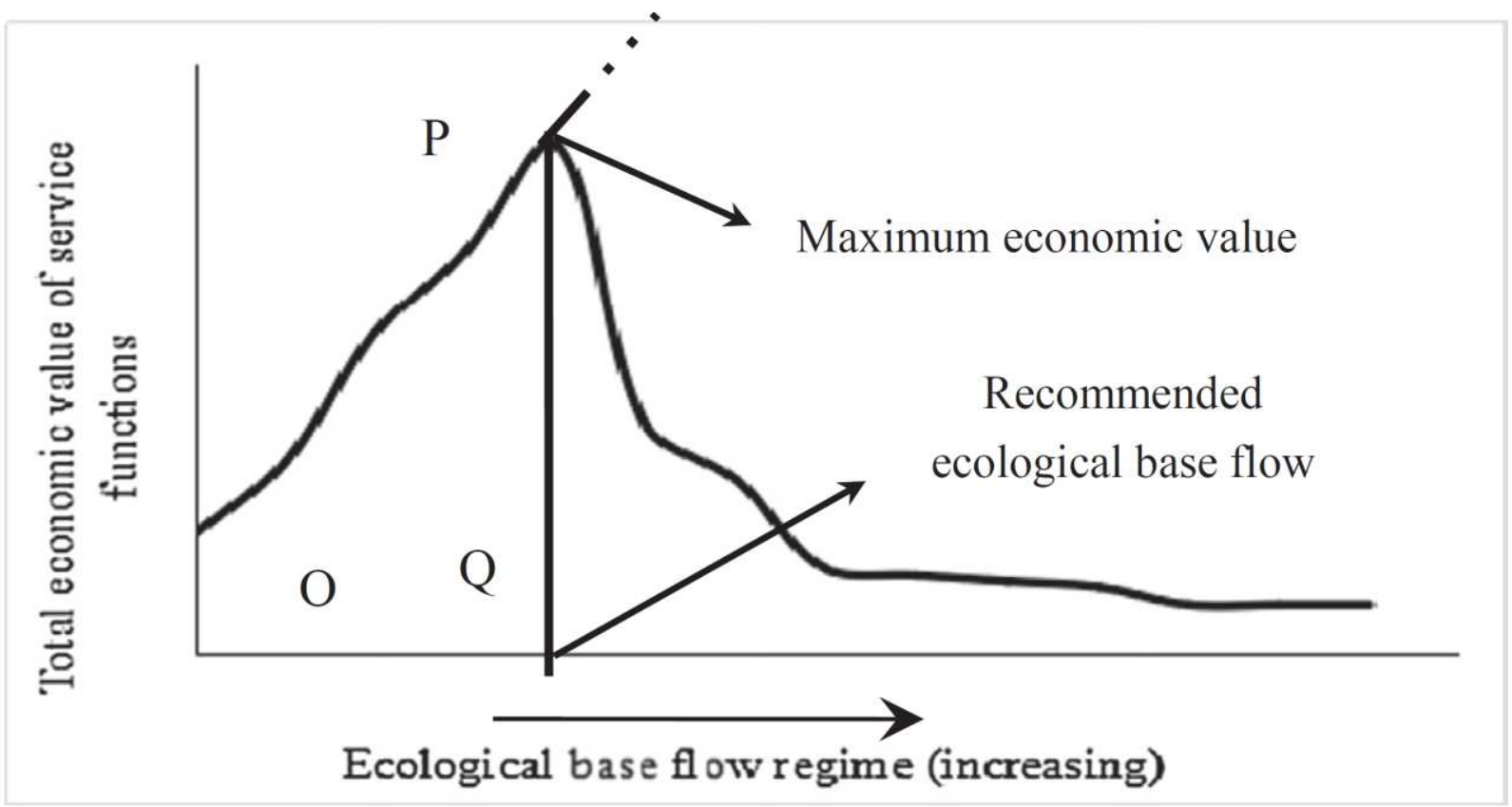

Fig.1 Change processes of the total economic value of rivers and recommended e-flow (Cheng et al. 2019).

\subsection{Water-related ecosystem services of wetland}

Wetlands are versatile ecosystems that provide ecosystem services necessary for the social and economic wellbeing of the local communities living near or around wetlands (Roy et al. 2012). Wetland goods and services can be valued in quantitative and monitory form regardless of the availability of its market price. The wetland quantified value can then be compared with other sectors of the economy for planning, policy formulation, and decisions making (Adekola et al. 2015).

The services from wetland include provisioning services (food, water, fish, fiber, fuel, timber); regulating services (regulation of flood, drought, air quality, land degradation, climate, disease, 
and natural hazard regulation); supporting services (soil formation and nutrient cycling); cultural services (recreational and ecotourism) and other non-material benefits (MEA 2005).

Wetlands are endangered by numerous factors, such as continuing population growth and economic expansion in coastal areas, unreasonable utilization, increased aquaculture and expanding residential regions, the underappreciated value of wetlands, and inappropriate definitions of wetlands in laws and regulations. Among these factors, the misunderstanding of the value of wetlands in public decisions is an essential issue. In recent years, many studies have evaluated the ecosystem services of the wetland (Xu et al. 2020). Ecosystem services are very diverse and one single method is not suitable to measure all the services (Körner and Paulsen 2004). Therefore, this study uses multiple methods to estimate the market and socio-economic values of the ecosystem services. This study has followed 5 major methods for quantifying the monetary values of wetland services namely; the market price method (Barbier et al. 1997), the travel cost method (Vicente and de Frutos 2011), the benefits transfer method (Johnston et al. 2015), Damage Cost Avoided, Replacement Cost or Substitute Cost Method (Zhang 2017) and the contingent valuation method (Thapa et al. 2020)

In Table 1, the most important services of Kani Barazan wetland are briefly discussed and the method of calculating each one is shown.

Table 1. Kani Barazan wetland ecosystem services and the evaluation methods used.

\begin{tabular}{|l|c|c|c|c|}
\hline Classification & Function & Evaluation & Calculation & Parameters \\
& & method & formula & \\
\hline
\end{tabular}




\begin{tabular}{|c|c|c|c|c|}
\hline Provisioning & $\begin{array}{l}\text { Agriculture products, } \\
\text { raw materials }\end{array}$ & Market price & $\begin{array}{c}\mathrm{Vp}=\sum_{\mathrm{i}=1}^{\mathrm{n}} \mathrm{Si} * \\
\mathrm{Wi} * \mathrm{Pi}\end{array}$ & $\begin{array}{l}\text { Si is the harvested area; } \\
\text { Yi is the per unit yield; } \\
\mathrm{Pi} \text { is the market value; } \\
\text { i stands for some product. }\end{array}$ \\
\hline \multirow[t]{2}{*}{ Regulating } & Climate Regulation & $\begin{array}{l}\text { Replacement } \\
\text { Cost }\end{array}$ & $\begin{array}{c}\mathrm{Wh}=\mathrm{S} * \mathrm{ET} * \\
\delta \\
\mathrm{Vc}=\eta * \mathrm{Wh} * \\
\mathrm{Pc}\end{array}$ & $\begin{array}{l}\text { Wh: the heat absorbed by a } \\
\text { wetland in summer (kJ); } \\
\text { Vc: the economic value of the } \\
\text { wetland cooling effect; } \\
\text { S: Wetland area(ha); } \\
\text { ET: indicates water surface } \\
\text { evaporation in summer (mm); } \\
\delta \text { : is the heat of evaporation } \\
\quad(\mathrm{kJ} / \mathrm{kg}) \text {; } \\
\text { pc: is the electricity fee in Iran } \\
\text { (USD } / \mathrm{kwh} \text { ); } \\
\text { no } 10-4) \text {. } \\
\text { coefficient between electrical }\end{array}$ \\
\hline & Water Supply & $\begin{array}{l}\text { Replacement } \\
\text { Cost }\end{array}$ & $\mathrm{Vw}=\mathrm{RC} * \mathrm{CC}$ & $\begin{array}{l}\text { Vw: Value of water balance } \\
\text { RC: Reservoir capacity (m3) } \\
\text { CC: Construction cost of } \\
\text { reservoirs per unit (USD/m3) }\end{array}$ \\
\hline
\end{tabular}




\begin{tabular}{|c|c|c|c|c|}
\hline & $\begin{array}{l}\text { Nutrient Recycling / } \\
\text { Water Quality / } \\
\text { Pollution Reduction }\end{array}$ & $\begin{array}{c}\text { Replacement } \\
\text { Cost }\end{array}$ & $\begin{array}{c}\mathrm{Vq}=\mathrm{S} * \mathrm{~N} * \\
\mathrm{P}_{\mathrm{N}}+\mathrm{S} * \mathrm{P} * \mathrm{P}_{\mathrm{P}}\end{array}$ & $\begin{array}{l}\text { Vq: Value of water quality } \\
\text { improvement } \\
\mathrm{S} \text { : Area of wetland (ha) } \\
\mathrm{Nj} \text { : Removal rates of } \mathrm{N} \text { of } \\
\text { wetland (kg/ha) } \\
\text { Pj: Removal rates of } \mathrm{P} \text { of } \\
\text { wetland (kg/ha) } \\
\text { Qnv: Cost of } \mathrm{N} \text { removal } \\
\text { (USD/kgN) } \\
\text { Qpv: Cost of } \mathrm{P} \text { removal } \\
\text { (USD/kgP) }\end{array}$ \\
\hline Supporting & Habitat & $\begin{array}{l}\text { Benefit } \\
\text { transfer }\end{array}$ & $\mathrm{Vh}=\mathrm{S} * \mathrm{Ph}$ & $\begin{array}{c}\text { Vh: Value of habitat } \\
\text { Sj: Area of wetland } \\
\text { Ph: Value of habitat per unit } \\
\text { area of wetland } \mathrm{j}(\mathrm{USD} / \mathrm{hm} 2)\end{array}$ \\
\hline \multirow{2}{*}{ Cultural services } & $\begin{array}{l}\text { Recreation and } \\
\text { tourism }\end{array}$ & $\begin{array}{c}\text { Travel cost } \\
\text { method }\end{array}$ & $\mathrm{Vr}=\mathrm{Q} * \mathrm{Y} * \mathrm{D}$ & $\begin{array}{l}\text { Q is the environmental } \\
\text { capacity; } \\
\text { Y is the travel consumption per } \\
\text { person; } \\
\text { d is the traveling days }\end{array}$ \\
\hline & Cultural \& education & $\begin{array}{l}\text { Benefit } \\
\text { transfer }\end{array}$ & $\mathrm{Ve}=\mathrm{S} * \mathrm{Pe}$ & $\begin{array}{l}\text { Vh: Value of Cultural \& } \\
\text { education } \\
\mathrm{Sj} \text { : Area of wetland } \\
\mathrm{Ph} \text { : Value of Cultural \& } \\
\text { education per unit area of } \\
\text { wetland j (USD/hm2) }\end{array}$ \\
\hline
\end{tabular}


Therefore, the economic value of the wetland ecosystem services (EVWES) is obtained from the total of the mentioned services.

$\mathrm{EVWES}=\mathrm{Vp}+\mathrm{Vc}+\mathrm{Vw}+\mathrm{Vq}+\mathrm{Vh}+\mathrm{Vr}+\mathrm{Ve}$

\subsection{Economic Value of Agriculture sector}

For decades, agriculture has been associated with the production of essential food crops. Most people's main source of livelihood is farming. About $70 \%$ of people rely directly on agriculture as a livelihood (Fao 2016). Agriculture is the main source of national income for most developing countries. Therefore, planning for the development of agricultural sectors and allocating suitable water for irrigation is an important issue that should be given special attention. Therefore, in this research, we have tried to achieve the highest economic efficiency by determining the area under cultivation and the appropriate cultivation pattern downstream of Mahabad Dam. The most important crops grown in the area are wheat, alfalfa and sugar beet. The specifications of these products are given in Table 2.

Table 2. Specifications of Mahabad plain crops

\begin{tabular}{|c|c|c|c|c|c|}
\hline Product & $\begin{array}{l}\text { Product yield } \\
(\mathrm{kg} / \mathrm{ha})\end{array}$ & $\begin{array}{r}\text { Product price } \\
(\text { rials } / \mathrm{kg})\end{array}$ & $\begin{array}{l}\text { Planting } \\
\text { date }\end{array}$ & $\begin{array}{l}\text { Harvesting } \\
\text { date }\end{array}$ & $\begin{array}{r}\text { Irrigation } \\
\text { period (day) }\end{array}$ \\
\hline Wheat & 3832 & 4200 & $20 \mathrm{Oct}$ & 1 July & 10 \\
\hline Alfalfa & 8684 & 3500 & $19 \mathrm{Mar}$ & $5 \mathrm{Dec}$ & 10 \\
\hline Sugar beet & 3234 & 8400 & $2 \mathrm{Dec}$ & $3 \mathrm{Oct}$ & 10 \\
\hline
\end{tabular}


The amount of economic value obtained from the agricultural sector is calculated using Equation 1.

$E V A=\left[\sum_{i=1}^{n} A_{i} \cdot B_{i} \cdot C_{i} \cdot\right]$

In the above equation, the parameters used are: EVA is the economic value of the agriculture sector which is the annual sales revenue of crops, $A_{i}$ is the area under cultivation of crop $i$ in hectares, $i$ in hectares, $B_{i}$ is price sales per kilogram of product in dollars, $C_{i}$ is the annual yield of product $i$ in kilograms per hectare

\subsection{Simulation-optimization approach}

Given the complexities of efficient water allocation planning, mathematical models provide the opportunity to model the hydrological processes associated with the water resources system and the relationships between supply and demand points. In general, water resources management models are divided into three types: simulation, optimization and simulation-optimization.

Simulation models use a set of relationships and parameters to predict system behavior and reconstruct the behavior of a water resources system according to set of (real or hypothetical) rules. Optimization models are based on maximizing or minimizing an objective function, which is based on a number of predetermined decision variables and constraints. The strength of simulation models is their ability to account for water resources systems with all the components and details possible, but solving many water resources problems requires the use of optimization models.

In this research, WEAP model is used for simulation and PSO algorithm is employed for optimization. Figure 2 shows the process of the optimization-simulation model. 


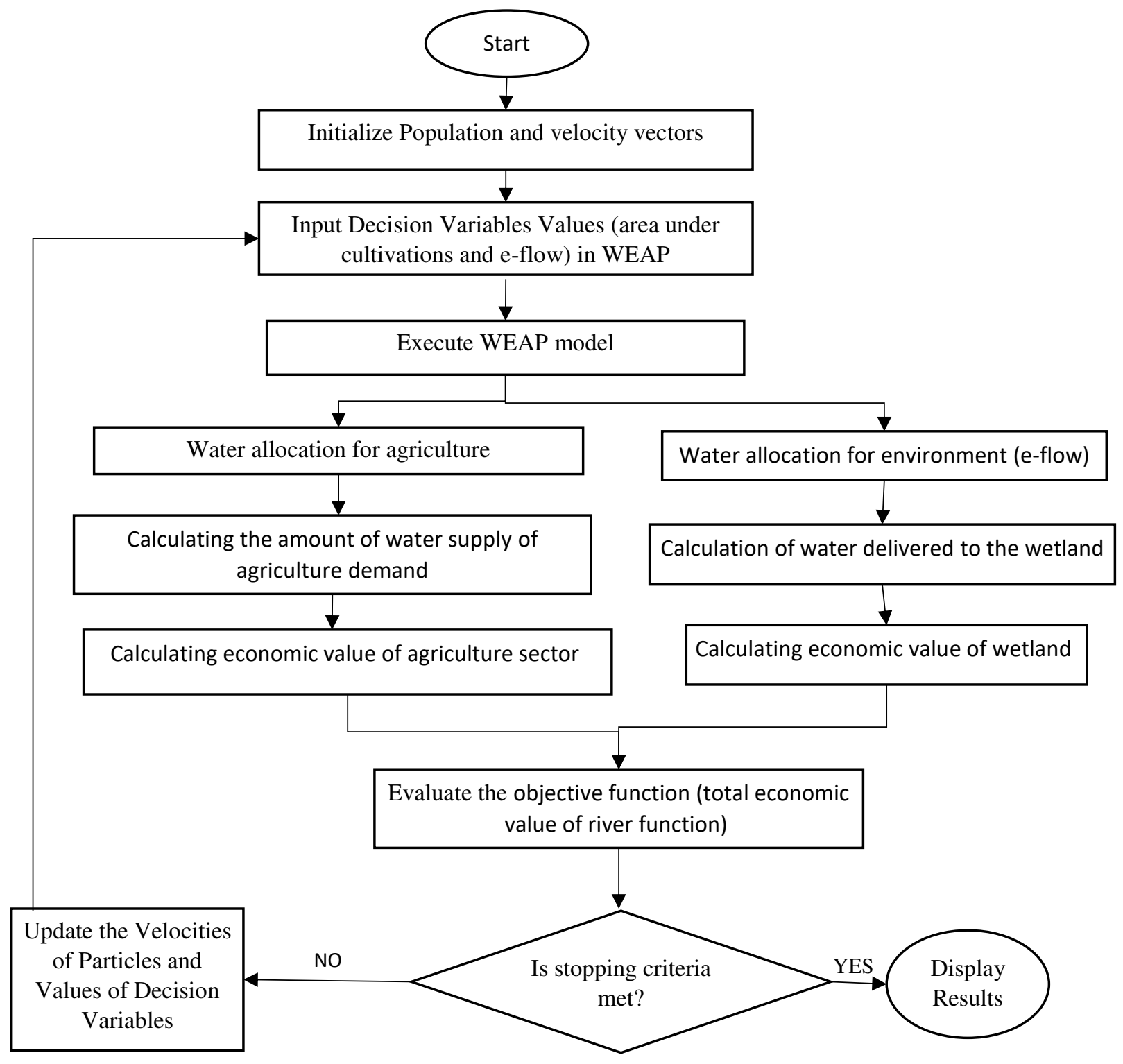

Fig. 2 Flowchart of optimization-simulation model

\subsubsection{Optimization model}

Planning and managing water resources at the basin level is a very complex and large problem.

Due to the multiplicity of resources and uses, the limitation of water resources, and the effects of 
different sectors on each other, the allocation and planning of water resources should be done in such a way that according to the available water resources, all goals are best met. In this study, there two objectives are considered, namely, maximization of economic value from the agricultural sector (EVA) and maximization of economic value of wetland ecosystem services (EVWES), which are considered in one objective function. The problem decision variables are the area under cultivation of agricultural units downstream of Mahabad Dam and the e-flow of Kani-Barazan wetland. The following is the formulation of the optimization problem.

$$
\mathrm{MAX} T E V=(E V A+\text { EVWES })
$$

$$
\begin{aligned}
& \mathrm{A}_{\mathrm{i}}=\left(\Sigma \operatorname{Agr}_{\mathrm{a}}-\Sigma\left(\operatorname{Agr}_{\mathrm{a}} \times\left|\beta_{\mathrm{i}}-\operatorname{Tar} \beta\right| \times \mathrm{P}\right)\right. \\
& \forall \mathrm{a}=1, \ldots, \mathrm{A}
\end{aligned}
$$

Subject to:

$$
\begin{gathered}
\mathrm{S}_{\mathrm{t}+1}=\mathrm{S}_{\mathrm{t}}+\mathrm{I}_{\mathrm{t}}-\mathrm{EV}_{\mathrm{t}}\left(\mathrm{S}_{\mathrm{t}+1}, \mathrm{~S}_{\mathrm{t}}\right)-\mathrm{R}_{\mathrm{t}} \quad \forall \mathrm{t}=1, \ldots, \mathrm{T} \\
\mathrm{S}_{\min , \mathrm{d}}(\mathrm{MOL}) \leq \mathrm{S}_{\mathrm{t}} \leq \mathrm{S}_{\max }(\mathrm{NWL}) \quad \forall \mathrm{t}=1, \ldots, \mathrm{T} \\
\mathrm{R}_{\mathrm{t}}=\mathrm{R}_{\mathrm{t}}\left(\mathrm{S}_{\mathrm{t}}, \mathrm{I}_{\mathrm{t}}\right) \quad \forall \mathrm{t}=1, \ldots, \mathrm{T} \\
\mathrm{SD}_{\mathrm{t}, \mathrm{i}} \leq \mathrm{D}_{\mathrm{t}, \mathrm{i}} \quad \forall \mathrm{t}=1, \ldots, \mathrm{T} ; \mathrm{i}=1, \ldots, \mathrm{I} \\
\text { if } \mathrm{SD}_{\mathrm{t}, \mathrm{i}} \times \mathrm{Z}_{\mathrm{t}, \mathrm{i}} \geq \mathrm{D}_{\mathrm{t}, \mathrm{i}} \quad \forall \mathrm{t}=1, \ldots, \mathrm{T} ; \mathrm{i}=1, \ldots, \mathrm{I} \\
\frac{\sum_{\mathrm{t}=1}^{\mathrm{T}} \mathrm{Z}_{\mathrm{t}, \mathrm{i}}}{\mathrm{T}}=\beta_{\mathrm{i}} \quad \forall \mathrm{i}=1, \ldots, \mathrm{I}
\end{gathered}
$$

A description of the utilized indices and variables is provided as follows: 
t: index related to time steps,

T: Number of time steps

$S_{t, d}$ : storage volume of reservoir $\mathrm{d}$ at the beginning of the time step $\mathrm{t}(\mathrm{MCM})$,

$I_{t, d}$ : inflow to reservoir $\mathrm{d}$ at the time step $\mathrm{t}(\mathrm{MCM})$

$E V_{t, d}\left(S_{t+1, d}, S_{t, d}\right)$ : net evaporation volume from reservoir $\mathrm{d}$ at the time step $\mathrm{t}$ as a function of the reservoir storage at the beginning and end of the step (MCM),

$R_{t, d}:$ water release volume from reservoir $\mathrm{d}$ at the time step $\mathrm{t}(\mathrm{MCM})$,

$S_{\min , d}$ : minimum operation volume (dead storage) of reservoir d as a function of the MOL (MCM),

$S_{\max , d}:$ normal water volume (storage capacity) d as a function of NWL (MCM),

i: index related to the water demand nodes,

I: number of demand nodes

$D_{t, i}:$ volume of water demand at the demand node $\mathrm{i}$ and time step $\mathrm{t}(\mathrm{MCM})$,

$S D_{t, i}$ : volume of allocated water to the demand node i and time step t (MCM),

$Z_{t, i}$ : binary variable related to meeting the demands at demand node $\mathrm{i}$ at time step $\mathrm{t}$. If the demand is completely fulfilled would be equal to 1 , otherwise, it would be zero.

$\beta_{i}:$ minimum desirable level of reliability related to supplying demands,

$A=$ Number of agriculture development sectors

$\mathrm{n}$ : is the index related to the system nodes, which can be between 1 and $\mathrm{N}$. 
In equation 1, the first objective is defined as the total economic value of the basin which is the sum of economic value of agriculture sector and economic value of wetland ecosystem services. Equation 2 is the amount of the penalty, which is applied in case of a reliability violation. that the amount of agricultural crop areas is determined according to the reliability of supplying their demands. So, the reliability of supplying demands could not be less than $80 \%$ (Hatamkhani and Moridi 2019). The penalty coefficient (PC) is found by trial and error and is set to 0.01 .

Equation (3) is related to the monthly water balance of each reservoir. In Equation (4), the monthly reservoir storage volume is limited to the minimum operation volume and normal water volume. Equation (5) is associated with the monthly operation policy of reservoirs as a function of storage volume and inflow. Equation (7) emphasizes that the volume of water that is actually allocated to a demand site at a time period should be less than or equal to the volume of water demand of the site. The time reliability of demand nodes of the system is controlled by equations (8) and (9).

\subsubsection{WEAP}

WEAP model is a tool for integrated planning of water resources, which has provided a comprehensive, flexible, and user-friendly framework for planning and analyzing policies (Sieber and Purkey, 2011). The WEAP model uses linear programming to solve water allocation problems at any time step and its objective function is to maximize the percentage of supplying demands, concerning supply and demand priority, mass balance, and other constraints. This software is widely used for integrated management and planning of water resources and has the river, economic, and agricultural demand management submodels.

\subsubsection{PSO Algorithm}

Particle swarm optimization (PSO) is a swarm intelligence algorithm based on the social behavior 
of birds. In this algorithm, a particle chooses a direction using the current position and its best position in the previous iterations (pbest) and also the best position in the whole swarm (gbest). The particles move to new positions, and the objective function values are calculated bsased on pbest and gbest in each iteration. This process is repeated until stopping criteria is met. In the PSO algorithm, each particle is a candidate solution equivalent to a point in a D-dimensional space, so the ith particle can be represented as $\left.X_{i}=\left(x_{i 1}, x_{i 2}, \ldots x_{i D}\right)^{D}\right)$. The rate of the ith particle's position change is given by its velocity $V_{i}=\left(v_{i 1}, v_{i 2}, \ldots v_{i D}\right)^{D}$. Equation (10) updates the velocity for each particle in the next iteration, whereas Equation (11) updates each particle's position in the search space:

$$
\begin{aligned}
& v_{i d}^{n+1}=\chi\left[W v_{i d}^{n}+C_{1} r_{1}^{n}\left(P_{i d}^{n}-x_{i d}^{n}\right)+C_{2} r_{2}^{n}\left(P_{g d}^{n}-x_{i d}^{n}\right)\right] \\
& x_{i d}^{n+1}=x_{i d}^{n}+v_{i d}^{n+1}
\end{aligned}
$$

In these equations $d=1,2, \ldots, D ; i=1,2, \ldots, N$, and $N$ is the size of the swarm; $x$ is called the constriction factor which is used in constrained optimization problems to control the magnitude of the velocity. $\mathrm{W}$ is called inertia weight; $\mathrm{C}_{1}, \mathrm{C}_{2}$ are two positive constants, called cognitive and social parameters, respectively; $\mathrm{r}_{1}, \mathrm{r}_{2}$ are random numbers uniformly distributed in $[0,1]$; and $\mathrm{n}=$ $1,2, \ldots, \mathrm{n}_{\max }$, shows the iteration number.

\section{Results and Discussion}

\subsection{Case study}

The study area includes the Mahabad River catchment area in northwestern Iran and the province of West Azerbaijan. Mahabad river flows into the reservoir of Mahabad dam after originating from the heights. Downstream of this reservoir is the irrigated lands of Mahabad plain that are fed to 
irrigate the water of this reservoir. In addition, there is a need for drinking and industry in the city of Mahabad, which must be met from this reservoir. The location of the Mahabad catchment is shown in Figure 3.

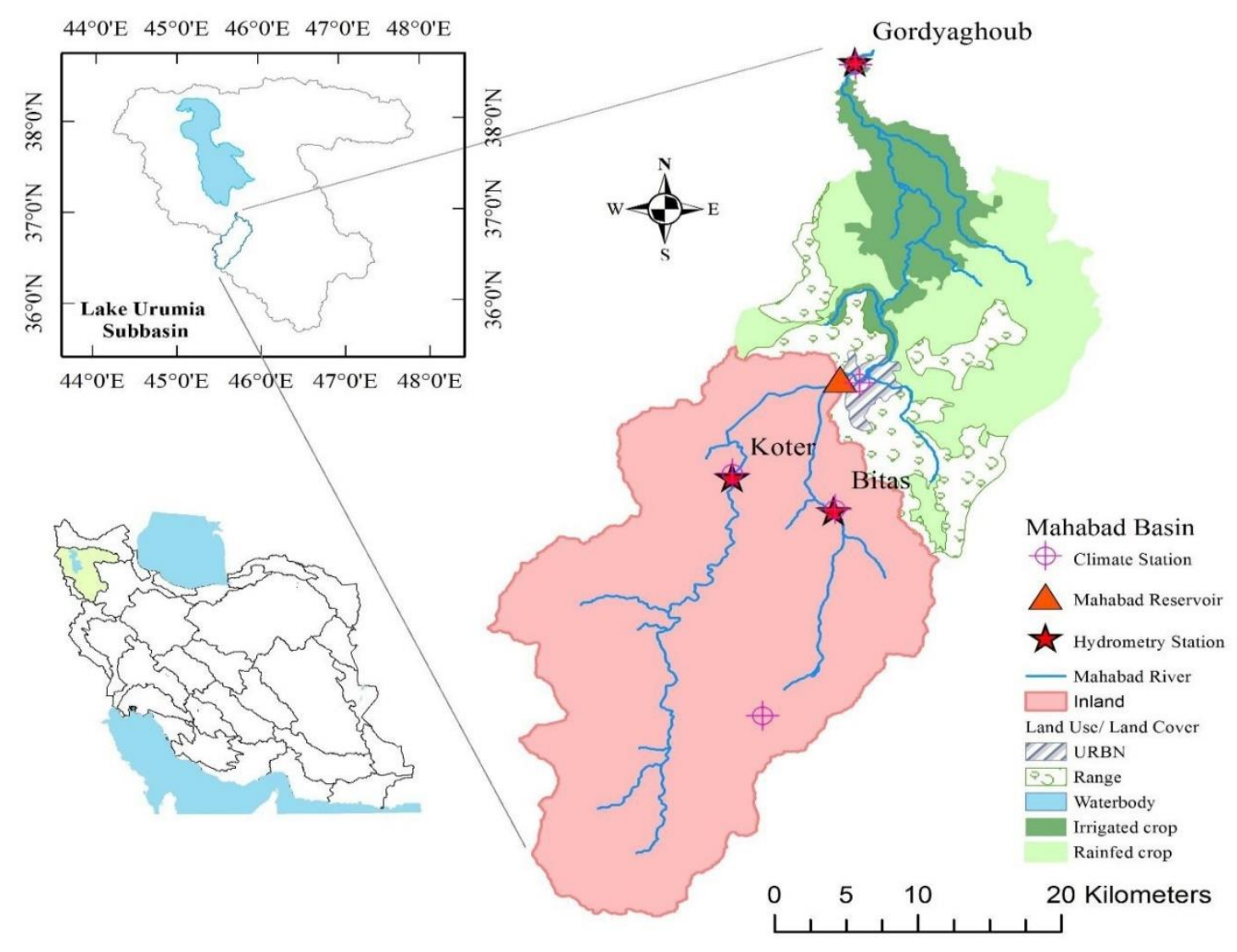

Fig3- Map of the Mahabad River Basin

Kani Barazan wetland is located $30 \mathrm{~km}$ north of Mahabad city and on the northern side of Qara Dagh mountain and in the geographical coordinates of 566820 to 571771 north latitude and 4093220 to 4097398 east longitude (based on UTM). This wetland includes 927 hectares of water in a 4010 hectares catchment area. This region is among the protected areas of West Azerbaijan province, although in terms of size; It has a small area but is very important in terms of ecological 
role. This region is one of the 4 sites of Ramsar and as an international wetland in the province of West Azerbaijan. Based on the study of wildlife in the region, 75 species of waterfowl and 105 species of the terrestrial; 12 species of reptiles, 5 species of amphibians, and 4 species of fish have been identified in the area.

\subsection{Economic Value of Kani Barazan Wetland}

Table 3 identified the most important functions and services of Kani Barazan wetland and the valuation method of each. The ecosystem services can be devided into four categories: (1) provisioning, (2) regulating, (3) cultural, and (4) supporting services. Among the seven ecosystem services, five (raw materials, water quality improvement, water balance, and climate regulation) were estimated in two steps. The first step was to estimate the physical dimension of each ecosystem service. The physical dimensions of the water balance were calculated based on DEM and land use data. These included $\mathrm{N}$ and $\mathrm{P}$ removal rates and water surface evaporation in summer. The second step was to calculate the value of each ecosystem service based on the physical dimension by the evaluation method. The market price method was used to assess the value of raw materials. The avoided cost method was used to estimate the water quality improvement, climate regulation, and water balance value.

The value of tourism activities can be based on income generated from tourists. This study incorporated tourism activities to estimate recreational value. We followed the travel cost method (TCM) and used a questionnaire to survey a recreational site (Haque et al. 2011). TCM is a survey technique where a questionnaire to a recreational site is often prepared and administered to estimate the recreation value of a site (Zarandi, 2019). In this study, we considered travel cost, direct expenses and opportunity costs of time of the visitors to calculate the value of recreational services from tourism. 
The values of the other ecosystem services with limited valuation data were estimated using a benefit transfer technique. Due to the relative similarity of the functions of Kani Barazan wetland with Choghakhor wetland, the studies conducted by the World Bank on Choghakhor wetland (World Bank 2015) in Iran were used as a basis for evaluating ecosystem services calculated by the benefit transfer method. Table 3 shows the economic value of ecosystem functions of Kani Barazan wetland per hectare per year.

Table 3- Economic value of ecosystem services of Kani Barazan wetland

\begin{tabular}{|c|c|c|}
\hline Classification & Function & $\begin{array}{c}\text { Economic Value } \\
\text { (\$/ha/year) }\end{array}$ \\
\hline \multirow{2}{*}{ Provisioning } & Materials Raw & 59 \\
\hline & Medical, industrial and nutrimental plants & 20 \\
\hline \multirow{3}{*}{ Regulating } & Climate Regulation & 77 \\
\hline & Water Supply & 59 \\
\hline & Nutrient Recycling / Water Quality / Pollution Reduction & 276 \\
\hline Supporting & Habitat & 302 \\
\hline \multirow[t]{2}{*}{ Cultural services } & $\begin{array}{c}\text { Recreation and tourism } \\
\text { (Hunting Fish \& watching Waterfowl) }\end{array}$ & 110 \\
\hline & Cultural \& education & 95 \\
\hline Total Value & - & $\begin{array}{l}998 \\
\end{array}$ \\
\hline
\end{tabular}

Therefore, considering the size of Kani Barazan wetland, the total economic value of ecosystem functions can be considered about \$ 1.08 million per year. 


\subsection{Simulation-Optimization Results}

As explained, the purpose of this study is to determine the optimal planning in the catchment to achieve an optimal trade-off between water allocation between agriculture and the environment. The purpose of the research is to maximize the total economic value of river functions which is the sum of economic value of agriculture sector and the economic value of wetland ecosystem services. According to Figure 4, the total economic value reaches a maximum value and then follows a decreasing trend. Therefore, simultaneously consideration of the cultivation pattern in the region and the water requirements of the wetland with regard to its ecosystem services for determining optimal planning and management of water resources is essential. The problem decision variables are area under cultivation of crops and e-flow of wetland. minimum and maximum limits of the decision variables are described in Table 4. It should be noted that the area under cultivations is calculated so that the constraint on the reliability level (80) is satisfied. The penalty function causes that the objective function tends to desirable reliability.

Table 4- The maximum and minimum values of decision variables

\begin{tabular}{|c|c|c|}
\hline Decision variable & Min & Max \\
\hline Area under cultivation of alfalfa (Ha) & 517 & 3876 \\
\hline Area under cultivation of wheat (Ha) & 647 & 4851 \\
\hline Area under cultivation of sugar beet (Ha) & 312 & 2342 \\
\hline e-flow of Kani Barazan (million $\mathrm{m}^{3} /$ month) & 1.33 & 0.166 \\
\hline
\end{tabular}

As mentioned, WEAP software has been used to simulate the water allocation in the catchment area. In water allocation, the domestic and industry demands are considered as the first priority. 
Then there are the needs of agriculture and the environment, which are included in the model with equal priority.

The PSO algorithm is employed to maximization the objective function. Given that the number of decision variables is problem 4, the number of particles in the PSO algorithm is considered 12. Figure 4 shows how the objective function converges to the best value.

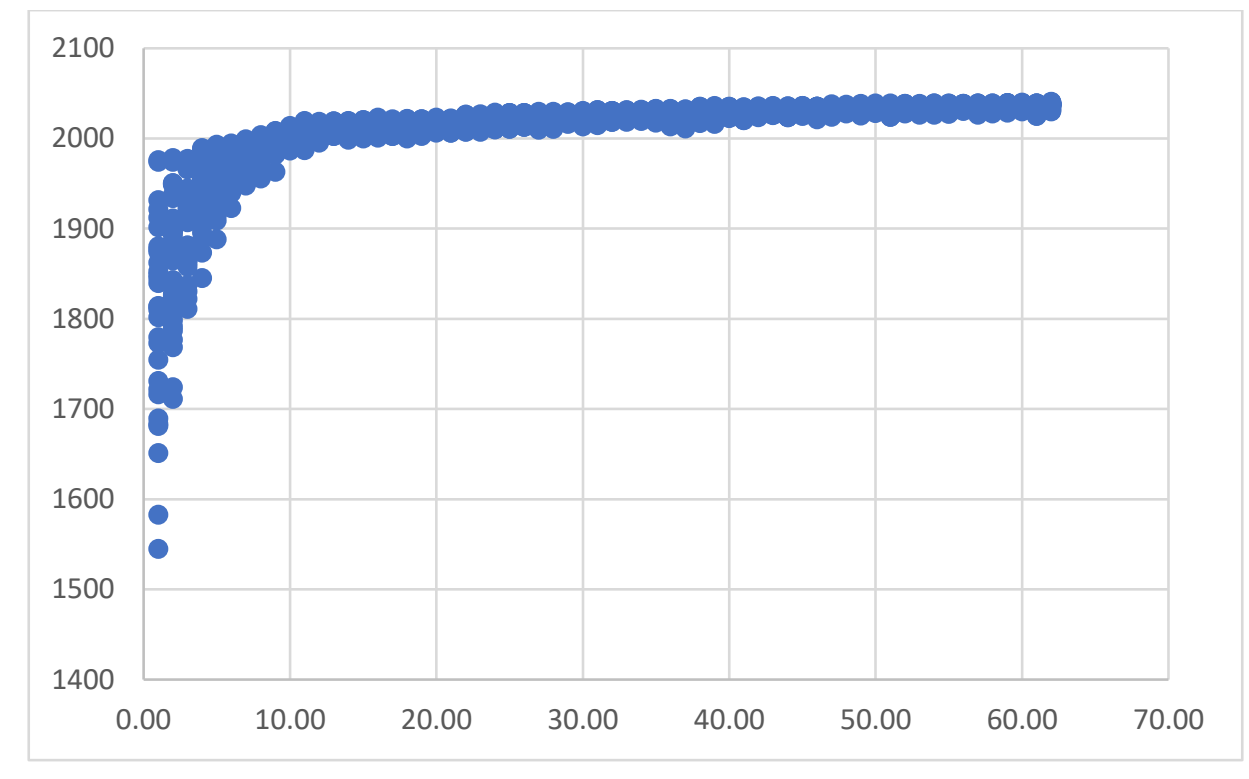

Fig.4 Convergence process of the objective function

According to the graph, the maximum total economic value of river functions is equal to 2040 billion rials. Which of these 1509.6 billion rials (74 percent) Related to the economic value of agriculture and 528.4 (26 percent) is related to wetland ecosystem services. Table 6 shows the optimal values of the decision variables and the objective function.

Table 6- Simulation-optimization (WEAP-PSO) model results

\begin{tabular}{|c|c|c|}
\hline Value & Optimal & Economic value \\
& value & \\
\hline The area under cultivation of alfalfa $(\mathrm{Ha})$ & 2336 & 347.7 \\
\hline The area under cultivation of wheat $(\mathrm{Ha})$ & 4851 & 580.3 \\
\hline
\end{tabular}




\begin{tabular}{|c|c|c|}
\hline The area under cultivation of sugar beet (Ha) & 1873 & 582.6 \\
\hline e-flow of Kani Barazan (million $\mathrm{m}^{3} /$ month) & 0.988 & 528.4 \\
\hline
\end{tabular}

According to the table, it is clear that the amount of area under wheat cultivation is equal to the value of its maximum limit. The main reason is that most of the water needs of wheat are in the months when the water needs of other crops, especially wetlands (summer) are lower. Changes in other crops are such that the allocation between water for agricultural products and the supply of ecological discharge to the wetland reaches an optimal balance. The area under sugar beet cultivation is less than alfalfa, which can be attributed to the yield per hectare and higher price of the crop. The last column of the table shows the reliability of meeting agricultural needs. As it is known, all products have good reliability, which can be justified due to the reliability constraint (Equation 2). The optimal environmental flow of Kani Barazan wetland is equal to $0.988 \mathrm{MCM}$ per month. Table 7 shows the sensitivity analysis of the decision variables and their effect on the objective function.

Table 7. Sensitivity analysis of decision variables

\begin{tabular}{|c|c|c|c|c|}
\hline Parameter & Levels/Value & $\begin{array}{c}\text { EVWES (Billion } \\
\text { Rials) }\end{array}$ & EVA (Billion Rials) & REV (Billion \\
\hline $\begin{array}{c}\text { Environmental flow } \\
\text { (MCM) }\end{array}$ & 0 & 0 & 2012.3 & 2012.3 \\
\hline $\begin{array}{c}\text { Agricultural cultivated } \\
\text { area (Ha) }\end{array}$ & 0 & 998 & 0 & 2098 \\
\hline $\begin{array}{c}\text { e-flow (MCM) } \\
\text { Agricultural cultivated } \\
\text { area (Ha) }\end{array}$ & $110 \%$ & 602.2 & 1410.7 & 2036.7 \\
\hline e-flow (MCM) & $90 \%$ & 480.3 & 1556.4 & 2023.2 \\
\hline
\end{tabular}




\begin{tabular}{|c|c|c|c|c|}
\hline $\begin{array}{c}\text { Agricultural cultivated } \\
\text { area (Ha) }\end{array}$ & $90 \%$ & 553.1 & 1399.3 & 1952.4 \\
\hline
\end{tabular}

If the values of e-flow are considered zero, the maximum economic value of agriculture is calculated equal to 2012.3 billion rials. If the area under agricultural cultivation is considered zero, the value of wetland ecosystem services will reach 998 billion rials, which is the maximum value of the wetland and wetland does not provide more services than this amount. It should be noted that if, for example, the e-flow rate increases by $10 \%$, although the value of the wetland ecosystem services has increased from 528.4 to 602.2 billion rials, this has reduced the value of the agricultural economic value by $6 \%$ (1410.7). So total economic value of the river has reached 2012.9 billion rials, which shows a $2 \%$ decrease in total economic value relative to the optimal solution. The opposite is also true. If the area under cultivation of each three crops increases by $10 \%$, in addition to reducing the value of the wetland ecosystem services to 480.3 billion rials, the economic value of the agricultural sector has increased by only $3.1 \%$ (1556.4 billion rials) due to the lack of adequate supply of agricultural demands. Decreasing the values of each of the decision variables also has a negative effect on the value of the total economic value. For example, when the area under cultivation is reduced by $10 \%$, the total economic value is reached to 1952.4 billion rials, which is reduced by $4.5 \%$ compared to the estimated optimal objective function (2039 billion rials). This indicates that the proposed model, regardless of the e-flow, prevents the unsustainable development of agricultural units. The results show that considering these two goals together in basin planning and designing the crop patterns and environmental flow, causes the greatest economic efficiency in the basin. 


\section{Conclusion}

In this study, a water allocation model is presented that in an integrated framework, considers the interaction of water supply and demand with respect to economic factors. In the water allocation process, the water supplier decides to allocate water under the influence of limited access to water resources and maximizing water supply revenue for different sectors. The construction of a model that can consider the impact of these factors simultaneously on the allocation of water resources is of particular importance for evaluating the effect of different policies on water allocation and the interests of stakeholders at the basin level. Despite their significant role in maintaining the healthy ecosystem and contribution to the local livelihoods of the people, wetlands are under threat due to degradation of catchments and water diversion leading to changes in water regimes. Many parts of the world have experienced loss or degradation of wetlands mainly due to agricultural use, urbanization, excessive exploitation by local populations, and poor planned developmental activities. In Iran are many wetlands are under serious threats because of unsuitable development of agriculture and the diversion of water supplies for irrigation. Estimate the value of e-flow and ecosystem services in monetary terms raise public awareness for the importance and protection of e-flow. Given that meeting the needs of agriculture and the environment are in conflict with each other, achieving a balance in the design and planning of the basin, based on both of these goals is very important. So, a simulation-optimization approach is employed for optimal planning at the basin and designing e-flow based on wetland ecosystem services. The WEAP model was used as a water allocation simulator and the PSO algorithm was employed as the optimization algorithm. The objective function of the problem was considered to be the total economic value of the river, which includes the economic value of the agricultural sector and the economic value of the wetland ecosystem services (which depends directly on the e-flow). The decision variables of the problem 
of cultivation areas of agricultural units and environmental flow of Kani Barazan wetland were considered. The results of the study indicate the importance of considering these two sectors (agriculture and environment) together. Considering the economic value for wetland ecosystem services plays an important role in the planning and sustainable management of water resources. On the one hand, it protects the e-flow and determines its appropriate amount, and on the other hand, its effect on the increase of the economic value of the river is evident.

Acknowledgments The authors thank reviewers for helpful comments in improving the manuscript.

Consent for Publication Herewith, we declare our consent for our manuscript to be published in "Water Resources Management” journal.

Conflict of Interest The authors have no conflicts of interest to declare that are relevant to the content of this article.

Funding The authors confirm that this article has no Funding.

Authors Contributions Both authors conceived and designed the study. Material preparation, data collection and analysis were performed by both authors.

Competing Interests The authors declare no competing interests.

Ethical Approval Not applicable

Consent to Participate Not applicable

Availability of data and materials Not applicable

\section{References}

1. Akter, S., Grafton, R. Q., \& Merritt, W. S. (2014). Integrated hydro-ecological and economic modeling of environmental flows: Macquarie Marshes, Australia. Agricultural Water Management, 145, 98-109. 
2. Adekola, O., Mitchell, G., \& Grainger, A. (2015). Inequality and ecosystem services: the value and social distribution of Niger Delta wetland services. Ecosystem Services, 12, 4254.

3. Barbier, Edward B., Mike Acreman, and Duncan Knowler. "Economic valuation of wetlands: a guide for policy makers and planners." Gland: Ramsar Convention Bureau, 1997.

4. Baral, S., Basnyat, B., Khanal, R., \& Gauli, K. (2016). A total economic valuation of wetland ecosystem services: An evidence from Jagadishpur Ramsar site, Nepal. The scientific world journal, 2016.

5. Belmar, O., Ibáñez, C., Forner, A., \& Caiola, N. (2019). The influence of flow regime on ecological quality, bird diversity, and shellfish fisheries in a Lowland Mediterranean River and its coastal area. Water, 11(5), 918.

6. Cheng, B., \& Li, H. (2020). Impact of climate change and human activities on economic values produced by ecosystem service functions of rivers in water shortage area of Northwest China. Environmental science and pollution research international.

7. Cheng, B., Li, H., Yue, S., \& Huang, K. (2019). A conceptual decision-making for the ecological base flow of rivers considering the economic value of ecosystem services of rivers in water shortage area of Northwest China. Journal of Hydrology, 578, 124126.

8. Cao, T.; Yi, Y.; Liu, H.; Yang, Z. Integrated ecosystem services-based calculation of ecological water demand for a macrophyte-dominated shallow lake. Glob. Ecol. Conserv. 2020, 21, e00858.

9. Bunn, S. E., \& Arthington, A. H. (2002). Basic principles and ecological consequences of altered flow regimes for aquatic biodiversity. Environmental management, 30(4), 492-507. 
10. Belmar, O., Booker, D., Álvarez-Cabria, M., Peñas, F. J., \& Barquín, J. (2019). Modelling physical characteristics of river habitats. River Research and Applications, 35(7), 804-817.

11. Davijani, M. H., Banihabib, M. E., Anvar, A. N., \& Hashemi, S. R. (2016). Optimization model for the allocation of water resources based on the maximization of employment in the agriculture and industry sectors. Journal of Hydrology, 533, 430-438.

12. Haavisto, R., Santos, D., \& Perrels, A. (2018). Determining payments for watershed services by hydro-economic modeling for optimal water allocation between agricultural and municipal water use. Water Resources and Economics, 26 (100127). doi:10.1016/j.wre.2018.08.003

13. Hatamkhani, A. \& Moridi, A. (2019). Multi-Objective Optimization of Hydropower and Agricultural Development at River Basin Scale Water Resour Manage 33: 4431. https://doi.org/10.1007/s11269-019-02365-X

14. Hatamkhani, A., \& Moridi, A. (2021). Optimal Development of Agricultural Sectors in the Basin Based on Economic Efficiency and Social Equality. Water Resources Management, $35(3), 917-932$.

15. Hatamkhani, A., Moridi, A., \& Yazdi, J. (2020). A simulation-optimization models for multi-reservoir hydropower systems design at watershed scale. Renewable Energy, 149, 253-263.

16. Poff, N.L.; Allan, J.D.; Bain, M.B.; Karr, J.R.; Prestegaard, K.L.; Richter, B.D.; Sparks, R.E.; Stromberg, J.C. The natural flow regime. BioScience 1997, 47, 769-784.

17. Driver, L. J., Cartwright, J. M., Knight, R. R., \& Wolfe, W. J. (2020). Species-Richness Responses to Water-Withdrawal Scenarios and Minimum Flow Levels: Evaluating 
Presumptive Standards in the Tennessee and Cumberland River Basins. Water, 12(5), 1334.

18. Li, X., Yu, X., Hou, X., Liu, Y., Li, H., Zhou, Y., ... \& Zhang, L. (2020). Valuation of Wetland Ecosystem Services in National Nature Reserves in China's Coastal Zones. Sustainability, 12(8), 3131.

19. Note, R. B., \& Brief, R. P. Implementing environmental flows with benefits for society and different wetland ecosystems in river systems.

20. Momblanch, A., Connor, J. D., Crossman, N. D., Paredes-Arquiola, J., \& Andreu, J. (2016). Using ecosystem services to represent the environment in hydro-economic models. Journal of Hydrology, 538, 293-303.

21. Moor, H., Hylander, K., \& Norberg, J. (2015). Predicting climate change effects on wetland ecosystem services using species distribution modeling and plant functional traits. Ambio, 44(1), 113-126.

22. Yue, S., Li, H., Cheng, B., \& Gao, Z. (2018). The value of environmental base flow in water-scarce basins: a case study of Wei River Basin, Northwest China. Water, 10(7), 848.

23. Xu, X., Chen, M., Yang, G., Jiang, B., \& Zhang, J. (2020). Wetland ecosystem services research: A critical review. Global Ecology and Conservation, e01027.

24. Yang, W., \& Yang, Z. (2014). Integrating ecosystem-service tradeoffs into environmental flows decisions for Baiyangdian Lake. Ecological engineering, 71, 539-550.

25. FAO. (2016). Increasing the resilience of agricultural livelihoods.

26. Sherafatpour, Z.; Roozbahani, A.; Hasani, Y. Agricultural Water Allocation by Integration of Hydro-Economic Modeling with Bayesian Networks and Random Forest Approaches. Water Resour. Manag. 2019, 33, 2277-2299. 
27. Karimi A, Ardakanian R (2010) Development of a dynamic long-term water allocation model for agriculture and industry water demands. Water Resour Manag 24:1717-1746

28. Millennium Ecosystem Assessment, 2005. Ecosystem and Human Well-being: Synthesis. Island Press, Washington, D.C.

29. Sieber J, Purkey D (2011) WEAP: Water Evaluation And Planning System. User Guide Somerville, MA: Stockholm Environment Institute, US Center.

30. Roozbahani, R., Schreider, S., Abbasi, B., 2013. Economic sharing of basin water resources between competing stakeholders. Water Resour. Manag. 27 (8), 2965-2988.

31. Thapa, S., Wang, L., Koirala, A., Shrestha, S., Bhattarai, S., \& Aye, W. N. (2020). Valuation of Ecosystem Services from an Important Wetland of Nepal: A Study from Begnas Watershed System. WETLANDS.

32. Qureshi, M. E., Connor, J., Kirby, M., \& Mainuddin, M. (2007). Economic assessment of acquiring water for environmental flows in the Murray Basin. Australian Journal of Agricultural and Resource Economics, 51(3), 283-303.

33. Pang, A., Sun, T., \& Yang, Z. (2014). A framework for determining recommended environmental flows for balancing agricultural and ecosystem water demands. Hydrological Sciences Journal, 59(3-4), 890-903.

34. Rebelo, A. J., Scheunders, P., Esler, K. J., \& Meire, P. (2017). Detecting, mapping and classifying wetland fragments at a landscape scale. Remote Sensing Applications: Society and Environment, 8, 212-223.

35. Roy, M.B., Samal, N.R., Roy, P.K. and Mazumdar, A. 2012. Impact of Land Use and Aquatic Plants on the Water Quality of the Sub-Tropical Alpine Wetlands in India: A Case 
Study using Neuro-Genetic Models. Journal of Water Resource and Protection. 4 (8) : 576589.

36. Underwood, E. C., Hollander, A. D., Huber, P. R., \& Schrader-Patton, C. (2018). Mapping the value of national forest landscapes for ecosystem service provision. In Valuing Chaparral (pp. 245-270). Springer, Cham.

37. Körner, C., \& Paulsen, J. (2004). A world-wide study of high altitude treeline temperatures. Journal of biogeography, 31(5), 713-732.

38. Vicente, E., \& de Frutos, P. (2011). Application of the travel cost method to estimate the economic value of cultural goods: Blockbuster art exhibitions. Revista de Economia Pública, 196(1), 37-63.

39. Johnston, R. J., Rolfe, J., Rosenberger, R. S., \& Brouwer, R. (2015). Benefit transfer of environmental and resource values. The economics of non-market goods and resources, 14.

40. Zhang, B.; Shi, Y.T.; Liu, J.H.; Xu, J.; Xie, G.D. Economic values and dominant providers of key ecosystem services of wetlands in Beijing, China. Ecol. Indic. 2017, 77, 48-58.

41. Zarandi, M. T. P., Abesht, A., Abedi, S., \& Ahangari, I. (2019). The Estimation of Economic Value of Wetland Ecosystem Protection and Recreational Services: Case Study of the Kanibrazan International Wetland. 